\title{
SKOR QUALITY OF LIFE PASIEN KANKER SERVIKS STADIUM LANJUT SETELAH MENDAPAT INTERVENSI PSIKOKURATIF
}

\section{Quality of Life Score of Patient Cancer Stadium Services after Getting Psychocuratives Intervention}

\author{
Soetrisno, Erindra Budi Cahyanto, Sri Mulyani, Angesti Nugraheni, Hafi Nurinasari \\ Program Studi Kebidanan Program Sarjana Terapan FK UNS \\ email:erindrabudi2007@yahoo.com
}

\begin{abstract}
ABSTRAK
Latar Belakang: Kanker menimbulkan berbagai gangguan kesehatan dan kesejahteraan hidup. Penyakit dan terapi kanker sendiri menimbulkan beban psikologis yang berat. Idealnya, suatu pengobatan seharusnya tidak hanya memperpanjang kelangsungan hidup dan periode bebas dari penyakit, tetapi juga menurunkan gejala penyakit, tidak menyebabkan efek samping, dan meningkatkan kemampuan individu kembali pada kehidupan normal. Namun pasien kanker yang mendapat kemoterapi mengalami efek samping tidak hanya pada aspek fisik saja, tetapi juga psikologis, sosial, dan spiritual sehingga dapat menurunkan kualitas hidup.

Metode: Jenis penelitian experimental double blind randomized clinical trial pre-test posttest group design. Subjek adalah pasien kanker serviks stadium lanjut (IIB-IV). Lima belas subjek mendapat psikokuratif, dan lima belas subjek lainnya sebagai kontrol hanya mendapat supportif/ terapi standart. Psikokuratif diberikan seminggu sekali selama empat kali kepada masing-masing subjek kelompok perlakuan selama 60 menit sekali secara bersama-sama setiap hari Senin. Subjek juga melakukan psikokuratif mandiri, berpedoman pada buku pintar psikokuratif yang telah dibagikan. Peneliti melakukan kunjungan rumah untuk memonitor dan memotivasi subjek agar dengan benar melakukan psikokuratif mandiri. Pengumpulan data dengan kuesioner kualitas hidup menurut WHO. Analisis data dengan uji beda pada program SPSS.

Hasil: Satu orang subjek pada kelompok kontrol meninggal dunia. Pada kelompok perlakuan, rerata skor kualitas hidup adalah 21,17 dan kontrol 16,33. Data kelompok perlakuan dan kontrol kemudian dianalisis dengan uji beda didapatkan hasil signifikan ( $\mathrm{p}=$ $0,001)$.
\end{abstract}

Simpulan: Penelitian menunjukan bahwa psikokuratif meningkatkan kualitas hidup pasien kanker serviks stadium lanjut.

Kata Kunci : Psikokuratif, Kualitas Hidup, Kanker Serviks Stadium Lanjut 


\section{ABSTRACT}

Background: Cancer raises various health problems and welfare of life. Disease and cancer therapy itself causes a heavy psychological burden. Ideally, a treatment should not only extend survival and a free period of disease, but also reduce symptoms of the disease, not cause side effects, and increase the ability of individuals to return to normal life. However, cancer patients who receive chemotherapy experience side effects not only on the physical aspects, but also psychological, social, and spiritual so that it can reduce the quality of life.

Method: This type of experimental research is double blind randomized clinical trial pretest post-test group design. Subjects were patients with advanced cervical cancer (IIB-IV). Fifteen subjects were psychocurative, and fifteen other subjects as controls only received standard supportive / therapy. psychocuratives was given once a week for four times to each subject of the treatment group for 60 minutes once every Monday. The subject also did an independent psychocuratives, based on psychocurative smart books that had been distributed. The researcher conducted a home visit to monitor and motivate the subjects to properly conduct an independent psychocuratives. Data collection by quality of life questionnaire according to WHO. Data analysis with different tests on the SPSS program.

Results: One subject in the control group died. In the treatment group, the average quality of life score was 21.17 and control was 16.33. The data of the treatment and control groups were then analyzed using a different test to obtain significant results $(p=0.001)$.

Conclusion: The conclusions of the study showed that psychocuratives improve the quality of life of patients with advanced cervical cancer.

Keywords: Psychocurative, Quality of Life, Advanced Stage Cervical Cancer

\section{LATAR BELAKANG}

Pasien kanker serviks stadium lanjut mengalami stress, baik berupa stress biologis (progresifitas penyakit dan terapi), stress psikologis (kecemasan terkait diagnosis, prognosis, biaya terapi medis, takut kematian), serta stress sosial (dukungan keluarga, tekanan ekonomi, dan lingkungan). Akibat paparan stressor yang berlangsung lama dapat terjadi depresi sehingga menurunkan kualitas hidup. Banyak peneliti telah meninjau upaya reduksi stress sebagai suatu cara untuk memperbaiki kualitas hidup dan daya tahan pasien kanker. Terdapatnya hubungan antara faktor psikologis dan fungsi sistem imun, inflamasi, pertumbuhan pembuluh darah, dan perkembangan tumor telah mengarahkan banyak peneliti pada pertanyaan apakah intervensi psikokuratif dapat membantu menurunkan gejala, menghambat rekurensi, dan meningkatkan daya tahan hidup pasien kanker $^{[1]}$.
Kanker menimbulkan berbagai gangguan kesehatan dan kesejahteraan hidup.Penyakit dan terapi kanker sendiri menimbulkan beban psikologis yang berat.Idealnya, suatu pengobatan seharusnya tidak hanya memperpanjang kelangsungan hidup dan periode bebas dari penyakit, tetapi juga menurunkan gejala penyakit, tidak menyebabkan efek samping, dan meningkatkan kemampuan individu kembali pada kehidupan normal $^{[2]}$. Pasien kanker serviks umumnya mendapat terapi kemoterapi dan radioterapi. Kedua terapi ini menimbulkan efek samping tidak hanya pada aspek fisik saja, tetapi juga psikologis, sosial, dan spiritual sehingga dapat menurunkan kualitas hidup ${ }^{[3]}$.

Penelitian ini bertujuan mengetahui kualitas hidup pasien kanker serviks stadium lanjut setelah mendapat intervensi psikokuratif. 


\section{SUBJEK DAN METODE}

Tempat pengambilan data subjek di bangsal dan poliklinik Obstetri dan Ginekologi Rumah Sakit Umum Daerah (RSUD) Dr.Moewardi Surakarta. Jenis penelitian ini adalah experimental double blind randomized clinical trial pretestpost-test group design. Subjek adalah Pasien kanker stadium lanjut (IIB-IV) yang berobat di RSUD Dr. Moewardi Surakarta sebanyak tiga puluh orang. Kriteria eksklusi meliputi penderita kanker pada organ lain selain serviks, sedang dalam masa kehamilan, menderita kelainan endokrin, mengalami gangguan mental berat (psikotik), dan terdapat riwayat pengobatan depresi. Alat ukur menggunakan kuesioner quality of live menurut WHO.

Kelompok perlakuan diberikan psikokuratif bersama sebanyak empat pertemuan masing-masing 60 menit di RSUD Dr.Moewardi. Setiap selesai psikokuratif dilakukan diskusi dan eksplorasi hal-hal yang dialami pada/ selama psikokuratif sebelumnya. Selain itu subjek melakukan psikokuratif individual seminggu tiga kali di rumah dengan panduan buku pintar psikokuratif yang telah diberikan oleh peneliti. Peneliti melakukan kunjungan ke masing-masing rumah subjek, untuk memonitor dan memotivasi subjek serta diskusi dan eksplorasi hal-hal yang berhubungan dengan penelitian.

Kelompok kontrol tidak mendapatkan psikokuratif, tetapi mendapatkan psikoterapi suportif/ terapi standar/ chemoradiasi saja, serta dilakukan pada hari yang berbeda dengan kelompok perlakuan agar tidak menyalahi etika dan tetap menghargai hak-hak pasien untuk mendapatkan layanan komprehensif sesuai standar rumah sakit. Analisis data dengan uji beda.

\section{HASIL}

\section{Karakteristik Subjek Penelitian}

Awalnya subjek sebanyak 30 orang pasien kanker serviks stadium lanjut di
RSUD Dr. Moewardi Surakarta dibagi dalam 2 kelompok yaitu sebanyak 15 pasien kelompok perlakuan dan 15 pasien kontrol. Dalam perkembangannya, jumlah subjek berkurang menjadi 29 orang karena salah satu subjek pada kelompok kontrol meninggal dunia.

\section{Kualitas Hidup}

Uji beda rerata kualitas hidup sesudah perlakuan ditampilkan pada tabel 1 .

Tabel 1. Uji beda rerata skor kualitas hidup setelah perlakuan

\begin{tabular}{lccc}
\hline Kelompok & $\begin{array}{c}\text { Jumlah } \\
\text { subjek }\end{array}$ & $\begin{array}{c}\text { Rerata } \\
\text { skor }\end{array}$ & P \\
\hline Perlakuan & 15 & 21,17 & 0.001 \\
Kontrol & 14 & 16,33 & \\
\hline
\end{tabular}

Pada tabel 1 tampak bahwa uji beda rerata skor kualitas hidup antara kelompok perlakuan dan kontrol dengan menggunakan uji $\mathrm{T}$ tidak berpasangan secara statistik bermakna $(\mathrm{p}<0.05)$.

\section{PEMBAHASAN}

Penelitian ini awalnya mengikutkan subjek sebanyak tiga puluh orang pasien kanker serviks stadium lanjut (IIB-IV) yang memenuhi kriteria inklusi dan eksklusi. Namun pada perkembangannya salah satu subjek pada kelompok kontrol meninggal dunia sehingga di akhir penelitian, jumlah subjek dua puluh sembilan orang.

Psikokuratif adalah intervensi psikologis yang diciptakan, dengan tujuan meyakinkan bahwa seseorang memiliki kesempatan yang lebih baik untuk menyesuaikan diri pada kondisi dan situasi kejiwaan mereka, sehingga dapat mengubah komponen pengetahuan terdahulu dan mendapatkan pemahaman baru untuk mengubah perilaku menjadi lebih baik.Intervensi di maksud adalah upaya pengobatan yang diciptakan dengan tujuan menyakinkan bahwa seseorang memiliki kesempatan yang lebih baik untuk menyesuaikan diri pada kondisi dan situasi kejiwaan mereka dan 
membangun hubungan harmonis dan intregral untuk meningkatkan stabilitas psikologis dan kemampuan hidup ${ }^{[4]}$.

Psikokuratif terdiri atas dukungan kognitif, spiritual, sosial dan fisik yang dapat mengubah kondisi distress menjadi eustress. Psikokuratif dipersepsi oleh otak, selanjutnya otak mengirimkan sinyal ke Automatic Nervous System (ANS) yang mempunyai bagian simpatik dan para simpatik. Pengaruh kondisi distress yang ditandai dengan peningkatan kadar kortisol terdapat pada sistem limbik tepatnya di hipothalamus. Dalam hal ini yang berperan adalah neuroglia yaitu astrosit ${ }^{[4]}$.

Psikokuratif merupakan sebuah aliran psikologi atau psikiatri modern yang menjadikan makna hidup sebagai tema sentralnya. Secara umum psikokuratif dapat digambarkan sebagai corak psikologi/ psikiatri yang mengakui adanya dimensi kerohanian pada manusia disamping dimensi ragawi dan kejiwaan, serta beranggapan bahwa makna hidup (the meaning of life) dan hasrat hidup bermakna (the will to meaning) merupakan motivasi utama manusia guna meraih taraf kehidupan bermakna (the meaningful life) yang didambakan ${ }^{[5]}$. Pada pasien kanker serviks stadium lanjut, masalah psikologis utama adalah ketakutan pasien pada penyakit tersebut. Ketakutan ini muncul karena kurangnya pemahaman pasien mengenai penyakit tersebut.

Tabel 1 menunjukan bahwa rerata skor kualitas hidup pada kelompok perlakuan lebih tinggi dari pada kelompok kontrol. Hasil uji beda menyebutkan terdapat perbedaan rerata skorkualitas hidup yang signifikan antara kelompok perlakuan dan kontrol dengan p sebesar 0,001 .

Pemberian psikokuratif dapat meningkatkan kualitas hidup, karena pemberian intervensi psikokuratif yang sesuai meliputi dukungan kognitif, spiritual, sosial, dan fisik akan mengubah kondisi distress menjadi eustress, menyebabkan perubahan emosi positif, dapat memicu ekspresi gen yang menguntungkan. Psikokuratif dapat bermanfaat dalam meningkatkan makna hidup pasien dengan mengurangi penderitaan pada pasien kanker stadium lanjut $^{[6]}$.

Setelah pemberian psikokuratif, dilakukan eksplorasi perasaan subjek. Banyak subjek yang merasa senang, tertawa bahagia setelah selesai melaksanakan psikokuratif. Emosional positif (tertawa) sangat menguntungkan pasien karena mampu mengekspresikan gen yang mengembalikan tubuh dalam kondisi keseimbangan (homeostasis) ${ }^{[7]}$. Kondisi demikian dalam kurun waktu yang lama akan berdampak pada peningkatan kualitas hidup. Peningkatan kualitas hidup juga akan meningkatkan survival rate sehingga pada kelompok perlakuan tidak ada yang meninggal sedang pada kontrol ada yang meninggal ${ }^{[8]}$.

\section{SIMPULAN}

Penelitian menunjukan bahwa psikokuratif meningkatkan kualitas hidup pasien kanker serviks stadium lanjut.

\section{SARAN}

Pemberian psikokuratif yang optimal dianjurkan untuk meningkatkan kualitas hidup pasien kanker serviks stadium lanjut.

\section{DAFTAR PUSTAKA}

1. Schettler T. 2013. The ecology of breast cancer: the promise of prevention and the hope for healing. Stress, social support, and breast cancer, h: 142-62.

2. King CR, Hinds PS. 2012. Quality of life: from nursing and patient perspectives. Jones and Barlett Publishers, United Kingdom.

3. Emmelia AFD. 2016. Perbedaan kualitas hidup pasien kanker serviks stadium lanjut pasca kemoterapi dan pasca radioterapi. Tesis. ETD Gadjah 
Mada University.

4. Soetrisno. 2009. Ekspresi heat shock protein 60, 70, 90, dan kortisol pada persalinan ibu primigravida yang mendapat psikokuratif. Disertasi. Surabaya: Universitas Airlangga.

5. Bastaman HD. 2007. Logoterapi: psikologi untuk menemukan makna hidup dan meraih hidup bermakna, Ed.I. Jakarta : PT Raja Grafindo Persada.

6. Kiecolt-Glaser JK, Robles TF, Heffner KL. 2002. Psycho-oncology and cancer: psychoneuroimmunology and cancer. Annals of Oncology, 13 S4, h: 165-169.

7. Ancuta B, Scurtu S, Shenker M. 2012. Quality of life in cervical cancer survivors. Acta Medica Marisiensis, 58(5); h: 275-277

8. Muñoz N, Bosch FX, de Sanjosé S. 2003. Epidemiologic classification of human papillomavirus types associated with cervical cancer, $N$ Engl J Med 348, h: 518-527. 